\title{
Shifting from N-based to P-based manure management maintains soil test phosphorus dynamics in a long-term corn and alfalfa rotation
}

\author{
Amir Sadeghpour ${ }^{1}$ • Quirine M. Ketterings ${ }^{1}$ • Gregory S. Godwin ${ }^{1}$ - Karl J. Czymmek ${ }^{1}$
}

Accepted: 7 February 2017 / Published online: 6 March 2017

(C) INRA and Springer-Verlag France 2017

\begin{abstract}
Multiyear repeated dairy manure application based on nitrogen $(\mathrm{N})$ needs of corn (Zea mays $\mathrm{L}$.) increases soil test phosphorus $(\mathrm{P})$ concentration and risk of $\mathrm{P}$ runoff over time. A $P$ removal based application of manure adds less $P$ but could impact yield. A corn field trial was implemented in New York in 2001 and rotated into alfalfa (Medicago sativa L.) in 2006 to examine soil test $\mathrm{P}$ dynamics over a corn-alfalfa rotation (2001 to 2011). Treatments were annual spring applications of $\mathrm{N}$-based versus $P$ removal based compost ( 74 and $46 \mathrm{Mg} \mathrm{ha}^{-1}$, respectively), liquid dairy manure (196 and $68 \mathrm{~m}^{3} \mathrm{ha}^{-1}$, respectively), and two control treatments $\left(0 \mathrm{~N}\right.$ and $112 \mathrm{~kg} \mathrm{ha}^{-1}$ sidedress $\mathrm{N}$ ). No manure or compost was applied during the alfalfa years. In the five corn years, Morgan-extractable soil test $\mathrm{P}$ concentrations increased 4 - and 2-fold for N-based and P-based manure and 6- and 4-fold for N-based and P-based compost, respectively, consistent with greater $\mathrm{P}$ balances possibly combined with differences in $\mathrm{P}$ fractions in each source. Soil test $\mathrm{P}$ concentrations declined in the alfalfa years but reached initial concentration only in the P-based manure system. Our findings show, for the first time in dairy forage rotations, the long-term sustainability benefits of P-based manure management and emphasize the importance of rotation fertility management rather than single-year P management. In conclusion, we demonstrated that a shift from N- to P-based manure allocation in corn years is a good approach to maintaining soil test $\mathrm{P}$ concentrations over the rotation while for higher application rates, a greater number of years in alfalfa than corn might be needed to prevent soil test $\mathrm{P}$ from building over the rotation.
\end{abstract}

Quirine M. Ketterings

qmk2@cornell.edu

1 Department of Animal Science, Cornell University, Ithaca, NY, USA
Keywords Corn $\cdot$ Manure source $\cdot$ Manure rate $\cdot$ Phosphorus balance $\cdot$ Soil test phosphorus

\section{Introduction}

In New York, dairy farming is the primary agricultural sector (USDA-NASS 2015) and 3-4 years of corn followed by 34 years of alfalfa or grass hay is the most common rotation on dairy farms in the state. To meet the nitrogen $(\mathrm{N})$ requirement of a corn crop, manure is often surface-applied in liquid or semisolid forms ( $\mathrm{N}$ based), leading to inefficient use of $\mathrm{N}$, over-fertilization of phosphorus $(\mathrm{P})$ and potassium $(\mathrm{K})$ compared with crop removal, and odor issues (Eghball and Power 1999; Toth et al. 2006; Sadeghpour et al. 2016a). When initial soil test P (STP) concentrations are low, overapplication of P can be desirable as it builds STP levels. However, in soils already high in P availability, excess P further elevates STP concentrations, increasing the risk of $\mathrm{P}$ runoff (Kleinman et al. 2002). A potential alternative that reduced $P$ balances is to shift from surface application of manure (N-based) to $\mathrm{P}$ removal based management with immediate $(<1 \mathrm{~h})$ incorporation (Sadeghpour et al. 2016a). The direct incorporation will increase the $\mathrm{N}$ value of manure through abating $\mathrm{N}$ volatilization (Meisinger et al. 2008; Ketterings et al. 2013; Sadeghpour et al. 2015).

An increase in STP concentration with fertilizer and manure amendments can be impacted by soil texture, $\mathrm{P}$ source, amount of $\mathrm{P}$ applied, and $\mathrm{P}$ balance ( $\mathrm{P}$ removed in yield minus $\mathrm{P}$ applied), and STP concentration increase varies among soil test extraction methods (Griffin et al. 2003; Haden et al. 2007). For example, greater STP (Mehlich-3) concentrations were found with $\mathrm{P}$ addition in sandy soils (48\%) than in clay loam soils $(37 \%)$ in a 6-week incubation study (Kumaragamage et al. 2011). 
A laboratory study by Kashem et al. (2004) showed greater STP concentration increase with monoammonium phosphate $\left(\mathrm{NH}_{4} \mathrm{H}_{2} \mathrm{PO}_{4}\right)$ as a $\mathrm{P}$ source than with hog and dairy cattle manure. Similarly, Kumaragamage et al. (2011) reported STP concentration (Mehlich-3 and Olsen extraction) increased more rapidly over an incubation period (6 weeks) with inorganic fertilizer than liquid swine manure, while STP concentration increase was quicker with liquid swine manure than solid swine manure. Studies by Griffin et al. (2003) and Haden et al. (2007) also found differences in efficiency of manure sources versus fertilizer sources in increasing STP concentration. They both reported that for the same change in STP concentration, more $\mathrm{P}$ had to be added as $\mathrm{NH}_{4} \mathrm{HPO}_{4}$ than needed to be added as superphosphate $\left[\mathrm{Ca}\left(\mathrm{H}_{2} \mathrm{PO}_{4}\right)_{2}\right]$ or liquid dairy manure, regardless of method of soil extraction (Morgan or Mehlich-3). Griffin et al. (2003) found the STP concentration increase was more pronounced with poultry manure than other sources of manure including dairy manure.

The amount of $\mathrm{P}$ applied influences the rate or magnitude of $\mathrm{P}$ accumulation in the soil as well. Toth et al. (2006) reported a $40 \mathrm{mg} \mathrm{kg}^{-1}$ increase in STP concentration (Mehlich-3) compared to the baseline levels when manure was applied based on the $\mathrm{N}$ needs of corn, orchardgrass (Dactylis glomerata L.), and alfalfa. No STP concentration increase was found with either zero $\mathrm{P}$ addition or P-based manure addition over a 4-year period (Toth et al. 2006). Only few studies have documented STP concentration increase per amount of $\mathrm{P}$ added. An example is a study by Eghball and Power (1999) which showed a linear increase in STP concentration (Bray-1) of $0.33 \mathrm{mg} \mathrm{kg}^{-1}$ with every kilogram addition of $\mathrm{P}$ (beef cattle manure, compost, and inorganic fertilizer) in a 4-year continuous grain corn cropping system.

A more realistic approach to quantify STP concentration buildup and understanding $\mathrm{P}$ dynamics than $\mathrm{P}$ application rate alone is to account for the amount of $\mathrm{P}$ removed by crops as well, deriving a $\mathrm{P}$ balance (difference between amount of $\mathrm{P}$ applied and removed by the crop). Huang et al. (2011) reported a $3.3 \mathrm{mg} \mathrm{P} \mathrm{kg}^{-1}$ increase in STP concentration (Olsen) with every $100 \mathrm{~kg}$ of positive $\mathrm{P}$ balance over 14 years of repeated inorganic fertilizer and horse manure plus inorganic fertilizer to soybean (Glycine max L.)-wheat (Triticum aestivum L.) and corn-wheat cropping systems. Likewise, Li et al. (2012) reported an average increase of $2.9 \mathrm{mg} \mathrm{kg}^{-1}$ in STP concentration (Olsen) in the plough layer $(0-20 \mathrm{~cm}$ depth) treated with biosolids (chicken manure and sewage sludge) for every $100 \mathrm{~kg} \mathrm{P} \mathrm{ha}^{-1}$ surplus $\mathrm{P}$ budget.

While several studies have evaluated STP concentration buildup as a function of a surplus P budget, only few studies report on STP concentration buildup and drawdown in longterm crop rotations. Notable exceptions include a study by Randall et al. (1997) who found that for every $\mathrm{mg} \mathrm{kg}^{-1}$ increase in STP concentration (Bray-1), $25 \mathrm{~kg}$ of applied $\mathrm{P} \mathrm{ha}^{-1}$ was needed over a 12 -year period. They reported that initial
STP levels impact the rate of STP concentration drawdown, and they showed STP concentration can be decreased to the initial levels after 8 years of cropping without $\mathrm{P}$ application. These results are different from those reported by Schulte and Kelling (1991) who suggested only $4.4 \mathrm{~kg} \mathrm{P} \mathrm{ha}^{-1}$ was needed to raise STP concentration (Bray-1) by $1 \mathrm{mg} \mathrm{kg}^{-1}$, reflecting previous land use leading to different $\mathrm{P}$ buffer capacity between the study sites. Dodd and Mallarino (2005) found that STP concentration (Bray-1) increased by 48 and $250 \mathrm{mg} \mathrm{kg}^{-1}$ with the application of $100 \mathrm{~kg} \mathrm{P} \mathrm{ha}^{-1}$ (triple superphosphate) in a 22-year grain corn-soybean rotation, while Mallarino and Prater (2007) reported that an annual crop removal of $23 \mathrm{~kg} \mathrm{P}$ $\mathrm{ha}^{-1}$ is needed to reduce STP concentration (Bray-1) by $1 \mathrm{mg} \mathrm{kg}^{-1}$ year $^{-1}$, suggesting that the rate of STP drawdown is slower than STP buildup (7.4 $\mathrm{kg} \mathrm{P} \mathrm{ha}^{-1}$ year $^{-1}$ to increase STP concentration by $1 \mathrm{mg} \mathrm{kg}^{-1}$ year $^{-1}$ ).

It is clear from the literature that STP concentration increases with higher rates of $\mathrm{P}$ addition. However, the literature that quantifies the changes in STP concentration buildup and drawdown over a long-term forage rotation managed with manure or compost is scant. The objective of this study was to evaluate the influence of a corn fertility management change from $\mathrm{N}$-based applications of manure and compost (without incorporation) to a $\mathrm{P}$ removal based management of manure (immediate tillage incorporation) and composted separated dairy solids on soil P dynamics over a 5-year corn and 5 -year alfalfa rotation.

\section{Materials and methods}

\subsection{Experimental site and weather condition}

The experimental area located in Aurora, NY $\left(42.73^{\circ} \mathrm{N}\right.$, $76.65^{\circ} \mathrm{W}, 253 \mathrm{~m}$ above sea level) was under continuous corn production and had no manure history prior to beginning of this study in 2001. The soil type was a tile-drained Lima silt loam texture (fine-loamy, mixed, active, mesic Oxyaquic Hapludalfs). The soil had an initial $\mathrm{pH}$ of 7.5 , organic matter content (by loss-on-ignition at $500{ }^{\circ} \mathrm{C}$ for $2 \mathrm{~h}$; Storer 1984) of $35 \mathrm{~g} \mathrm{~kg}^{-1}$, and Morgan extractable nitrate, STP, and soil test $\mathrm{K}$ concentration of $5.2,5.1$, and $47 \mathrm{mg} \mathrm{kg}^{-1}$, respectively (0$20 \mathrm{~cm}$ depth). The soil was classified as medium in $\mathrm{K}$ (Ketterings et al. 2003c) and high in P (Ketterings et al. 2003b). During the corn years, the mean air temperatures from May to October (growing season) were $17.5^{\circ} \mathrm{C}$ in 2001 , $17.1^{\circ} \mathrm{C}$ in $2002,17.0^{\circ} \mathrm{C}$ in $2003,17.2{ }^{\circ} \mathrm{C}$ in 2004 , and $18.5^{\circ} \mathrm{C}$ in 2005 . The mean air temperatures were $17.3,18.5$, $16.5,16.4$, and $17.7^{\circ} \mathrm{C}$ in 2006 through 2010 (alfalfa years), respectively, close to the 30-year (1980-2010) average $\left(17.3{ }^{\circ} \mathrm{C}\right)$ in Aurora, NY. In corn years, cumulative growing season precipitation was $430,506,573,652$, and $599 \mathrm{~mm}$ in 2001 through 2005, respectively. In alfalfa years, cumulative 
growing season precipitation was $738 \mathrm{~mm}$ in 2006, $391 \mathrm{~mm}$ in 2007, $519 \mathrm{~mm}$ in 2008, $495 \mathrm{~mm}$ in 2009, and $659 \mathrm{~mm}$ in 2010. The 30-year average precipitation in May, June, July, and August was 83, 97, 90, and $85 \mathrm{~mm}$, respectively. There were dry periods during July $(21 \mathrm{~mm})$ and August $(39 \mathrm{~mm})$ in 2002, May (25 mm) and July (52 mm) in 2005, and from May to October in 2007 , which were lower than the 30 -year average. Precipitation exceeded the average during July (138 mm) and August (142 mm) in 2004 and above the average from May to October in 2006 (alfalfa establishment year). The year 2007 was the driest during the 10-year of the study where every month had precipitation lower than the 30-year average (excluding October) which explains the very low alfalfa yield that year.

\subsection{Compost and manure sampling and analysis}

Two local dairy farms provided the compost and manure. Each year, we collected liquid dairy manure from agitated manure storage lagoons of a neighboring dairy farm. In the first 2 years of the study, manure solids were stacked outdoors on a soil pad in windrows and turned infrequently from April to November with finished compost in 9 to 12 months. In the latter 3 years of the study, compost was supplied by a farm that stacks separated manure solids indoors for 3 weeks at $65^{\circ} \mathrm{C}$ before moving the material outdoors for aerated pile composting with weekly turning for 3 to 4 months. Subsamples from all sources were collected before land application, kept cool at the time of collection, and frozen before sending to the laboratory for analysis. Manure and compost samples were analyzed at Dairy One Analytical Services, Inc. in Ithaca, NY. The Kjeldahl procedure with ammonia-N determination by distillation was used for total $\mathrm{N}$ analysis (AOAC 2000). Organic $N$ was calculated by subtracting ammonia-N from total $\mathrm{N}$. Total $\mathrm{P}$ content was analyzed by ICP (Thermo IRIS Advantage DX Inductively Coupled Plasma Radial Spectrometer, Thermo Electron Crop., San Jose, CA) (Sirois et al. 1994). Total solids were determined gravimetrically (oven at $100{ }^{\circ} \mathrm{C}$ for $16 \mathrm{~h}$ ) (Hoskins et al. 2003), and density was determined using a 51.5-ml standard vial (Dairy One 2007). Application rates of manure and compost for the initial design of the experiment were calculated based on the $\mathrm{N}$ and $\mathrm{P}$ compositions in 2001, prior to the first applications. However, application rates changed from year to year due to variability in manure and compost composition and changes in equipment availability as presented in Sadeghpour et al. (2016a). Averaged over the 5 years of the study, total $\mathrm{N}(\mathrm{TN})$, ammonia $\mathrm{N}$, organic $\mathrm{N}$ and $\mathrm{P}$, in manure were $3.4,1.7,1.7$, and $0.5 \mathrm{~g} \mathrm{~kg}^{-1}$, respectively. Total solid was $83.5 \mathrm{~g} \mathrm{~kg}^{-1}$ with an average total N/P ratio of 7.5. For compost, the average $\mathrm{TN}$, ammonia $\mathrm{N}$, organic $\mathrm{N}$, and $\mathrm{P}$ was 5.9, $0.2,5.7$, and $1.0 \mathrm{~g} \mathrm{~kg}^{-1}$, respectively, with a total solids content of $296.8 \mathrm{~g} \mathrm{~kg}^{-1}$ and N/P ratio of 6.1 (Sadeghpour et al. 2016a).

\subsection{Experimental design and cultural management practices}

\subsubsection{Experimental design and treatments}

A corn-alfalfa rotation experiment was initiated in 2001 and continued until April 2011. The field was under corn production from 2001 to 2005 and under alfalfa production from 2006 to 2011. Alfalfa was terminated in April of 2011. During the corn years, the six fertility treatments were: (1) annual spring applications of composted dairy solids at $\mathrm{P}$ removal based $\left(46 \mathrm{Mg} \mathrm{ha}^{-1}\right.$; average of 5 years), (2) annual spring applications of composted dairy solids at $\mathrm{N}$ based (74 $\mathrm{Mg} \mathrm{ha}^{-1}$; average of 5 years), (3) annual application of liquid dairy manure at $\mathrm{P}$ removal based (68 $\mathrm{m}^{3} \mathrm{ha}^{-1}$; average of 5 years), (4) annual application of liquid dairy manure at $\mathrm{N}$ based $\left(196 \mathrm{~m}^{3} \mathrm{ha}^{-1}\right.$; average of 5 years), (5) no $\mathrm{N}$ application (0 $\left.\mathrm{kg} \mathrm{N}^{-1}\right)$, and (6) optimum $\mathrm{N}$ fertilizer sidedress rate $\left(112 \mathrm{~kg} \mathrm{~N} \mathrm{ha}^{-1}\right)$ based on the most economical rate of $\mathrm{N}$ (MERN) based on LGU guidelines as documented in Ketterings et al. (2003a), which is supported by the findings of Sadeghpour et al. (2017). Treatments were set up in a randomized complete block design with five replicates. Corn was planted using $22 \mathrm{~kg} \mathrm{~N}, 10 \mathrm{~kg} \mathrm{P}$, and $18 \mathrm{~kg} \mathrm{~K} \mathrm{ha}^{-1}(28 \mathrm{~kg} \mathrm{~N}$, $13 \mathrm{~kg} \mathrm{P}$, and $23 \mathrm{~kg} \mathrm{~K} \mathrm{ha}^{-1}$ in 2003) banded as starter fertilizer $5 \mathrm{~cm}$ below and $5 \mathrm{~cm}$ to the side of the corn seed.

Nitrogen-based compost and manure application rates were designed to meet corn $\mathrm{N}$ needs in the 3rd year of application. The assumption was that organic $\mathrm{N}$ will build up in the first and the second years after application, supplying additional organic $\mathrm{N}$. Rates for P-based compost and manure were designed based on estimated corn P removal. The LGU determined yield potential for a Lima silt loam was $18 \mathrm{Mg}$ dry matter (DM) ha ${ }^{-1}$ (Ketterings et al. 2003a). Estimated corn $\mathrm{P}$ removal for a yield potential of $18 \mathrm{Mg} \mathrm{DM} \mathrm{ha}^{-1}$ was $95 \mathrm{~kg} \mathrm{P}_{2} \mathrm{O}_{5} \mathrm{ha}^{-1}$, assuming $2.3 \mathrm{~g} \mathrm{P} \mathrm{kg}^{-1}$ dry matter (average reported by Dairy One 2007). Based on algorithms outlined in Ketterings et al. (2003a), total N (starter plus sidedress) was estimated at $125-145 \mathrm{~kg} \mathrm{~N}^{-1}$. The inorganic $\mathrm{N}$ sidedress rate was $112 \mathrm{~kg} \mathrm{~N}^{-1}$ to meet the expected corn $\mathrm{N}$ requirement (134 $\mathrm{kg} \mathrm{N}^{-1}$ including $22 \mathrm{~kg} \mathrm{~N}^{-1}$ starter fertilizer). The availability of organic $\mathrm{N}$ for manure and compost was assumed to be 35 and $25 \%$ in the year of application, respectively, while organic $\mathrm{N}$ availability for both manure and compost was assumed to be 12 and $5 \%$ in the second and 3rd year after application (Ketterings et al. 2003a). Availability of the inorganic $\mathrm{N}$ fraction from compost (N-based and $\mathrm{P}$-based) and in $\mathrm{N}$-based manure was considered $0 \%$, reflecting ammonia volatilization with surface application of the manure and compost. Neither N-based nor P-based compost treatments were incorporated due to the small and insignificant inorganic $\mathrm{N}$ content in composted dairy solids. A $65 \%$ conservation of inorganic $\mathrm{N}$ 
was assumed with direct $(<1 \mathrm{~h})$ incorporation with a chisel plow after application in the P-based treatment (Ketterings et al. 2003a). Composted dairy solids were applied with a New Idea $1.66 \mathrm{~m}^{3}$ flail spreader (Agco Inc., Coldwater, OH). A Husky spreader (Husky Farm Equipment, Alma, ON) was used to apply liquid dairy manure and P-based manure treatments were immediately incorporated with a chisel plow to conserve the inorganic $\mathrm{N}$ in the manure right after application, while other treatments were left unincorporated until seedbed preparation five or more days after manure and compost application (Fig. 1). The optimum $\mathrm{N}$ rate $\left(112 \mathrm{~kg} \mathrm{~N} \mathrm{ha}^{-1}\right)$ was applied in mid-June using a John blue (four-row) sidedress unit with a LM-2450 metering pump (The Pump Co., Huntsville, AL). Excluding a $10 \mathrm{~kg} \mathrm{Pha}^{-1}$ and $18 \mathrm{~kg} \mathrm{~K} \mathrm{ha}^{-1}$ applied to alfalfa at planting, no N, P, or K was added to alfalfa for the rest of the trial from 2007 to 2010 .

Manure and compost composition resulted in year-to-year variability in application rates. In the corn phase of the rotation, the 5-year cumulative $\mathrm{P}$ applied in the $\mathrm{N}$-based manure was 451 versus $416 \mathrm{~kg} \mathrm{Pha}^{-1}$ in N-based compost (Table 1A), roughly 2 -fold greater than $220 \mathrm{~kg} \mathrm{Pha}^{-1}$, the expected $\mathrm{P}$ removal. The 5-year cumulative $\mathrm{P}$ application was $275 \mathrm{~kg} \mathrm{P} \mathrm{ha}^{-1}$ for P-based compost and $208 \mathrm{~kg} \mathrm{P} \mathrm{ha}^{-1}$ for the P-based manure treatment. In the alfalfa years, the $\mathrm{P}$ addition was limited to $10 \mathrm{~kg} \mathrm{P} \mathrm{ha}^{-1}$ applied in the establishment year. Therefore, $\mathrm{P}$ mining with alfalfa was expected for each treatment, depending on P supplying capacity of the soil and alfalfa yield.

\subsubsection{Cultural management practices}

Two corn varieties used in the trial were Dekalb DKC42-95 RR2/YGCB in 2004 and Pioneer 37M81in 2001 to 2003 and in 2005. Time of planting for corn ranged from May 5th (2005) to May 29th (2002), reflecting weather differences among years. Corn planting rate was 79,010 seeds ha ${ }^{-1}$ in 2001 and 101,730 seeds $\mathrm{ha}^{-1}$ in 2002. The seeding rate from 2003 to 2005 was 87,900 seeds $\mathrm{ha}^{-1}$. Corn was planted with a John Deere 7000 Max Emerge planter (John Deere, Moline, IL) with a row spacing of $76 \mathrm{~cm}$ across all treatments in each year. Alfalfa (variety WL345LH) was planted at the rate of $16.8 \mathrm{~kg} \mathrm{ha}^{-1}$ with a John Deere 450 grain drill (John Deere, Moline, IL) in April 21st 2006. Manure and compost plots (56 m long and $12 \mathrm{~m}$ wide) as well as fertilizer $\mathrm{N}$ plots ( $56 \mathrm{~m}$ long and $6 \mathrm{~m}$ wide) were chiselplowed, disked, and rolled once with a cultipacker before planting corn and alfalfa. Weed and pest control during the corn years is described in Sadeghpour et al. (2016a,b).

The alfalfa variety was leafhopper (Empoasca fabae Fabr.) resistant, and no pest or insect control was needed during the alfalfa years. To control weeds, alfalfa was clipped in July 6 th in 2006 and sprayed with ammonium salt of imazamox [2-[4,5-dihydro-4-methyl-4-(1-methylethyl)-5-oxo- $1 \mathrm{H}$ imidazol-2-yl]-5-(methoxymethyl)-3-pyridinecarboxylic acid] at the rate of $0.36 \mathrm{~kg}$ a.i. ha ${ }^{-1}$ on April 25th 2007. No further herbicide was used from 2008 to 2010 .

\subsection{Sampling and calculations}

\subsubsection{Soil sampling and analysis}

In the corn years, soil samples were collected 7 to 10 times $(0-$ $20 \mathrm{~cm}$ depth) during the growing season, starting just before manure and compost application and ending late fall. During the alfalfa years, soil samples were collected in spring and following each cut of alfalfa ranging from two times in 2006 to four times in 2008 to 2010. A final sampling round was
Fig. 1 Soil test $\mathrm{P}$ dynamics as impacted by $P$ removal based and $\mathrm{N}$-based manure and compost application during the corn years in a corn-alfalfa rotation. In this study, $\mathrm{P}$ removal based rates were incorporated within an hour after manure application with a chisel plow. All other treatments were incorporated at least 5 days following application

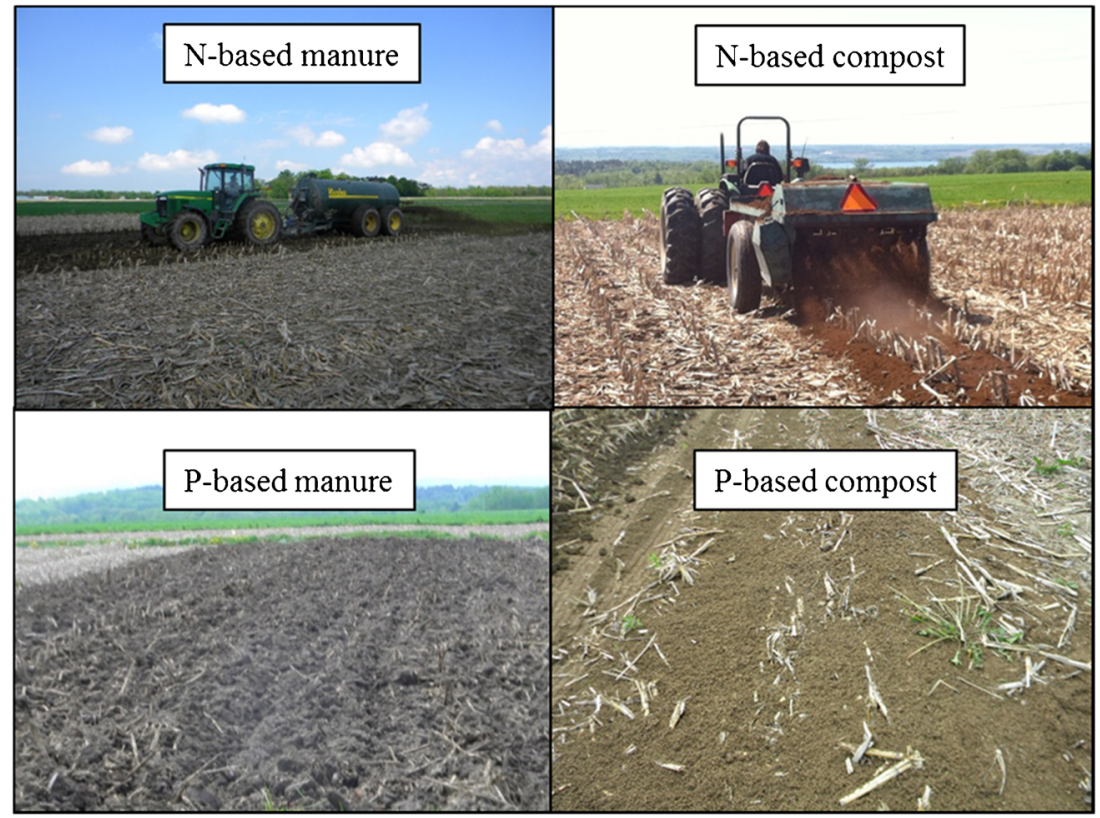


Table 1 Amount of phosphorus applied (A), corn and alfalfa dry matter (DM) yield (B), and phosphorus balance (C) during 2001 to 2005 (corn years) and 2005 to 2010 (alfalfa years) under composted dairy solids, liquid dairy manure, and inorganic $\mathrm{N}$ management

\begin{tabular}{|c|c|c|c|c|c|c|c|c|c|c|c|c|}
\hline \multirow[t]{3}{*}{ Treatment } & \multicolumn{12}{|c|}{ Growing season } \\
\hline & \multicolumn{5}{|l|}{ Corn } & \multicolumn{5}{|c|}{ Alfalfa } & \multirow{2}{*}{$\begin{array}{l}\text { Corn } \\
\text { 5-year total }\end{array}$} & \multirow{2}{*}{$\begin{array}{l}\text { Alfalfa } \\
\text { 5-year total }\end{array}$} \\
\hline & 2001 & 2002 & 2003 & 2004 & 2005 & 2006 & 2007 & 2008 & 2009 & 2010 & & \\
\hline (A) & \multicolumn{12}{|c|}{$\mathrm{P}$ applied $\left(\mathrm{kg} \mathrm{ha}^{-1}\right)$} \\
\hline $\mathrm{CN}$ & 80 & 83 & 79 & 106 & 68 & 10 & 0 & 0 & 0 & 0 & 416 & 10 \\
\hline $\mathrm{CP}$ & 51 & 56 & 52 & 63 & 53 & 10 & 0 & 0 & 0 & 0 & 275 & 10 \\
\hline $\mathrm{MN}$ & 122 & 74 & 115 & 79 & 111 & 10 & 0 & 0 & 0 & 0 & 501 & 10 \\
\hline MP & 50 & 37 & 42 & 40 & 49 & 10 & 0 & 0 & 0 & 0 & 218 & 10 \\
\hline $0 \mathrm{~N}$ & 10 & 10 & 12 & 10 & 10 & 10 & 0 & 0 & 0 & 0 & 52 & 10 \\
\hline $112 \mathrm{~N}$ & 10 & 10 & 12 & 10 & 10 & 10 & 0 & 0 & 0 & 0 & 52 & 10 \\
\hline (B) & \multicolumn{12}{|c|}{ Yield $\left(\mathrm{Mg} \mathrm{DM} \mathrm{ha}{ }^{-1}\right)$} \\
\hline $\mathrm{CN}$ & $10.9 \mathrm{c}$ & $5.9 \mathrm{ab}$ & $15.1 \mathrm{a}$ & $14.6 \mathrm{~b}$ & $13.8 \mathrm{ab}$ & $7.3 \mathrm{a}$ & $6.4 \mathrm{a}$ & $16.6 \mathrm{a}$ & $16.5 \mathrm{a}$ & $12.1 \mathrm{a}$ & 60.3 & 58.9 \\
\hline $\mathrm{CP}$ & $11.4 \mathrm{bc}$ & $7.0 \mathrm{a}$ & $14.2 \mathrm{a}$ & $14.1 \mathrm{~b}$ & $12.0 \mathrm{c}$ & $6.9 \mathrm{a}$ & $6.9 \mathrm{a}$ & $15.8 \mathrm{a}$ & $15.8 \mathrm{a}$ & $10.9 \mathrm{a}$ & 58.7 & 56.3 \\
\hline $\mathrm{MN}$ & $13.9 \mathrm{a}$ & $5.1 \mathrm{bc}$ & $16.4 \mathrm{a}$ & $16.4 \mathrm{a}$ & $15.6 \mathrm{a}$ & $7.2 \mathrm{a}$ & $6.7 \mathrm{a}$ & $16.5 \mathrm{a}$ & $17.4 \mathrm{a}$ & $12.0 \mathrm{a}$ & 67.4 & 59.8 \\
\hline MP & $12.6 \mathrm{abc}$ & $4.2 \mathrm{c}$ & $14.6 \mathrm{a}$ & $14.1 \mathrm{~b}$ & $13.8 \mathrm{ab}$ & $6.6 \mathrm{a}$ & $6.0 \mathrm{a}$ & $16.2 \mathrm{a}$ & $12.3 \mathrm{~b}$ & $7.5 \mathrm{~b}$ & 59.3 & 48.6 \\
\hline $0 \mathrm{~N}$ & $12.5 \mathrm{abc}$ & $6.3 \mathrm{ab}$ & $11.6 \mathrm{~b}$ & $11.3 \mathrm{c}$ & $11.2 \mathrm{c}$ & $6.4 \mathrm{a}$ & $6.5 \mathrm{a}$ & $13.4 \mathrm{~b}$ & $12.4 \mathrm{~b}$ & $7.5 \mathrm{~b}$ & 52.9 & 46.2 \\
\hline $112 \mathrm{~N}$ & $13.2 \mathrm{abc}$ & $5.9 \mathrm{ab}$ & $14.3 \mathrm{a}$ & $14.2 \mathrm{~b}$ & $12.8 \mathrm{bc}$ & $5.8 \mathrm{a}$ & $6.2 \mathrm{a}$ & $13.9 \mathrm{~b}$ & $10.4 \mathrm{~b}$ & $5.9 \mathrm{~b}$ & 60.4 & 42.2 \\
\hline (C) & \multicolumn{12}{|c|}{ P balance $\left(\mathrm{kg} \mathrm{ha}^{-1}\right)$} \\
\hline $\mathrm{CN}$ & 57 & 70 & 45 & 72 & 35 & -12 & -19 & -44 & -41 & -35 & $279 \mathrm{~b}$ & $-151 \mathrm{a}$ \\
\hline $\mathrm{CP}$ & 29 & 42 & 21 & 36 & 27 & -12 & -18 & -44 & -37 & -30 & $155 \mathrm{c}$ & $-141 \mathrm{a}$ \\
\hline $\mathrm{MN}$ & 96 & 64 & 82 & 48 & 78 & -12 & -19 & -47 & -43 & -36 & $367 \mathrm{a}$ & $-157 \mathrm{a}$ \\
\hline MP & 27 & 28 & 11 & 13 & 9 & -11 & -16 & -40 & -28 & -20 & $85 \mathrm{c}$ & $-115 b$ \\
\hline $0 \mathrm{~N}$ & -14 & -3 & -12 & -12 & -14 & -13 & -17 & -36 & -28 & -22 & $-54 \mathrm{~d}$ & $-116 b$ \\
\hline $112 \mathrm{~N}$ & -15 & -1 & -15 & -13 & -15 & -9 & -16 & -37 & -24 & -18 & $-59 \mathrm{~d}$ & $-104 \mathrm{~b}$ \\
\hline
\end{tabular}

Specific treatments include: N-based composted dairy solids $\left.\left(\mathrm{CN}, 74 \mathrm{Mg} \mathrm{ha}^{-1}\right), \mathrm{P}_{\text {removal based composted dairy solids }(\mathrm{CP}, 46 \mathrm{Mg} \text { ha }}{ }^{-1}\right), \mathrm{N}-$ based liquid dairy manure without incorporation (MN, $\left.196 \mathrm{~m}^{3} \mathrm{ha}^{-1}\right)$, P removal based liquid dairy manure with incorporation of manure directly following application (MP, $\left.68 \mathrm{~m}^{3} \mathrm{ha}^{-1}\right)$, starter $\mathrm{N}$ application only $(0 \mathrm{~N})$, and $112 \mathrm{~kg} \mathrm{~N} \mathrm{ha}^{-1}$ side-dressed $\mathrm{N}(112 \mathrm{~N})$. Means that are followed by different letters are significantly different $(P \leq 0.05)$

done in the spring of 2011. In April 2011, additional soil profile samples were taken from $0-5,5-20,20-30,30-40$, and $40-50 \mathrm{~cm}$ soil depths using a deep core sampler (Giddings Machine Company Inc., Ft. Collins, 201 CO). Stoniness of subsoil did not allow for soil sampling below $50 \mathrm{~cm}$ soil profile. After drying the soil samples in an oven $\left(<50{ }^{\circ} \mathrm{C}\right)$ for at least $48 \mathrm{~h}$, samples were crushed to pass a 2$\mathrm{mm}$ sieve. Standard procedures at Cornell University were followed while preparing the soil samples for available $\mathrm{P}$ analysis (Greweling and Peech 1965). Available P was determined using the Morgan extraction (Morgan 1941). Phosphorus in solution was determined colorimetrically (Murphy and Riley 1962) with a Technicon Autoanalyzer I (Pulse Instrumentation Ltd., Saskatoon, SK, Canada).

\subsubsection{Plant tissue sampling and analysis}

Corn plants (whole area) were harvested during September, ranging from September 5th in 2005 to September 21st in
2004. A whole-plant moisture content between 600 and $700 \mathrm{mg} \mathrm{kg}^{-1}$ was targeted to determine when to harvest the trial. Four rows in each plot were harvested to determine the silage yield using a Mex-Profi 2-row forage harvester Type $\mathrm{MH}$ 444 (Pöttinger, Grieskirchen, Austria) set at a cutting height of $20 \mathrm{~cm}$. Due to low silage yields in 2002 (drought year), grain yields (hand harvest of 0.002 ha per plot) were determined and converted to silage equivalents assuming $1 \mathrm{~kg}$ of grain equates $1.73 \mathrm{~kg}$ of silage DM (Ketterings et al. 2003a). At silage harvest time, a five-plant subsample from each plot was chopped in the field using a Model 120312 Mighty Mac, a gas-powered chipper-shredder (Mackissic Inc., Parker Ford, PA). Samples were mixed well, subsampled to fill a 3.78-L plastic bag, sealed, and kept in a cooler before drying in a $60{ }^{\circ} \mathrm{C}$ forced air oven for a minimum of $48 \mathrm{~h}$ to determine the moisture content.

Alfalfa harvest typically occurred at early flowering. Harvesting methods varied from year to year, reflecting equipment availability. A flail harvester (Carter Mfg. Co., Inc., Brookston, IN) at a $10-\mathrm{cm}$ stubble height was used during 
2006 growing season and for the 1 st cut in 2007. Alfalfa strips $(1.0 \times 6.1 \mathrm{~m})$ at a $10-\mathrm{cm}$ stubble height were harvested for yield with a Carter Harvester (Carter Mfg. Co., Inc., Brookston, IN) from the 2nd cut in 2007 through the last cutting in 2010 with the exception of 4th cut in 2008 growing season when a hand mower [GS model 700, Black and Decker (USA) Inc, Towson, MD] was used to harvest a 1.0-m-wide and 6.1-m-long sampling area (sum of the three sampling frames) at $10-\mathrm{cm}$ stubble height. Forage samples were ovendried at $60^{\circ} \mathrm{C}$ for $\mathrm{DM}$ determination.

In both corn and alfalfa, the oven-dried samples were ground to pass a $1-\mathrm{mm}$ screen, and tissue $P$ was analyzed with ICP (Thermo iCAP 6300 Inductively Coupled Plasma Radial Spectrometer, Thermo Scientifics, Waltham, MA).

\subsection{Phosphorus balance calculation}

The annual $\mathrm{P}$ balance was calculated by subtracting the amount of $\mathrm{P}$ applied in each treatment from the actual crop $\mathrm{P}$ uptake and removal with harvest. The $\mathrm{P}$ balance varied from year to year due to variability in manure composition, application rates, and annual differences in yield and forage mineral content. The 10 -year $\mathrm{P}$ balance was calculated by adding yearly balances from 2001 to 2010. Relationships between P balance during the corn and alfalfa years individually, and for the 10 -year rotation, were used to determine the impact of $\mathrm{P}$ addition beyond crop uptake or removal on STP dynamics over the rotation.

\subsection{Statistical analysis}

Data were analyzed using PROC Mixed in SAS (Littell et al. 1996; SAS Institute 2009). The experiment was set up in five blocks, and every plot within each block was repeatedly measured over the years. Thus, corn and alfalfa yield data were analyzed using a repeated measure approach with treatment, year, and the interaction of treatment by year as main effects and block and treatment nested within block (indicating plots) as random effects. In addition, an autoregressive covariance structure was specified for the plots being repeatedly measured over the years. For STP, initial levels $(0-20 \mathrm{~cm})$ varied from plot to plot at the start of the experiment in 2001. Thus, we normalized the STP levels of each of the plots at each sampling date and year in reference to the first initial value of the first year as was done in Sadeghpour et al. (2016a).

To evaluate the STP concentration buildup and drawdown over the rotation, three sampling dates were selected: April 2001 (initial sampling date), April 2006 (initial year in alfalfa), and April 2011 (the spring after the last year in alfalfa). Treatments and sampling dates and their interactions were considered fixed effects. Block and treatment nested within block (indicating plots) were considered random effects. In addition, an autoregressive covariance structure was specified for the plots being repeatedly measured over the sampling dates. To evaluate STP concentration in the soil profile (STP, 0-50 cm depth), STP concentration data were analyzed using a repeated measure approach with sampling depth, treatment, and the interaction as main effects and block and treatment nested within block (indicating plots) as random effects. In addition, autoregressive covariance structure was specified for the plots being repeatedly measured over the depths. Because the main focus of this study was to look at STP concentrations at each depth, the interaction of sampling date with treatment were sliced for sampling date to assess the differences among treatments at each sampling depth. For balance evaluations, PROC Mixed was used with treatments as fixed effect and block as random. We also used PROC Mixed with fertility treatments as fixed effects and block as random effect. Least square means were separated using the PDIFF option of LSMEANS in SAS PROC Mixed; least significant differences values are reported at $P \leq 0.05$. PROC Reg was used for determining the relationship between actual $\mathrm{P}$ balance and STP concentration.

\section{Results and discussion}

\subsection{Corn and alfalfa dry matter yields}

Corn DM yield (across all treatments) ranged from 5.7 to 14.3 $\mathrm{Mg} \mathrm{ha}^{-1}$ (Table 1B). Severe drought in the months of July and August explains the very low yield in 2002 (5.7 $\mathrm{Mg} \mathrm{ha}^{-1}$ across all treatments) (Table 1B). Nitrogenbased manure was the highest yielding $\left(16.2 \mathrm{Mg} \mathrm{ha}^{-1}\right)$ treatment in the last 3 years (after the 2 years of organic $\mathrm{N}$ accumulation by manure and compost), reflecting benefits of manure beyond $\mathrm{N}$ availability; possibly improved soil health and/ or greater water supply as $\mathrm{N}$-based manure applications resulted in the application of an addition of $19.6 \mathrm{~mm}$ of water. As reported in Sadeghpour et al. (2016a), shifting from N-based to P-based compost and manure management resulted in 7 and $13 \%$ yield and 8 and $9 \%$ crude protein reduction, indicating over-estimation of available $\mathrm{N}$ through direct incorporation of manure and, thus, a need for the addition of inorganic $\mathrm{N}$ as sidedress to avoid yield loss with P-based managements (Table 1B). A shift from compost (average of N-based and P-based management) to manure (average of $\mathrm{N}$-based and $\mathrm{P}$ based management) increased the yield by $13 \%$, indicating a need to re-evaluate the $\mathrm{N}$ crediting systems for availability of organic $\mathrm{N}$ in composted dairy solids.

Alfalfa DM yield (averaged over six treatments) ranged from $6.5 \mathrm{Mg} \mathrm{ha}^{-1}$ in 2007 to $15.4 \mathrm{Mg} \mathrm{ha}^{-1}$ in 2008 , reflecting weather conditions and the number of cuts in each year (Table 1B). Alfalfa DM yield was similar among all treatments in the establishment year (2006) and in the first production year (2007), the 2 years with weather extremes. While 
2006 was exceptionally wet (738 mm from May to October), 2007 was driest (391 mm from May to October) among the 10 years of the trial (2001 through 2010). Alfalfa DM yield was $2.6 \mathrm{Mg} \mathrm{ha}^{-1}$ greater in plots that had received manure or compost (averaged over N-based and P-based manure and compost) compared to those that had only received inorganic fertilizer (average of 0 and $112 \mathrm{~kg} \mathrm{~N} \mathrm{ha}^{-1}$ ) in the corn years, reflecting a clear benefit of manure and compost addition in the corn years for the alfalfa that follows in the rotation. With the average DM yield of $11.6 \mathrm{Mg} \mathrm{ha}^{-1}$, N-based manure and compost treatments (N-based and P-based) were consistently the highest yielding treatments during the alfalfa years, producing $21 \%$ more DM yield than average DM yield of Pbased manure and inorganic fertilizer treatments $(0$ and $112 \mathrm{~kg} \mathrm{~N} \mathrm{ha}^{-1}$ ). While a shift from N-based to P-based compost did not reduce the alfalfa DM yield, shifting from Nbased to P-based manure resulted in $22 \%$ yield reduction in the last 2 years of the study (2009 and 2010). Soil test P and K levels were still classified as high (Fig. 2; results for $\mathrm{K}$ not shown) in those 2 years, so the reduced yield is more likely to reflect differences in other nutrients, possibly sulfur (Ketterings et al. 2012). For this reason, it is recommended that producers check their alfalfa stand for sulfur status in later years in the rotation (Ketterings et al. 2012).

\subsection{Phosphorus balance}

The greatest 5-year P balance was obtained with N-based manure application $\left(367 \mathrm{~kg} \mathrm{Pha}^{-1}\right.$ ), which is $33 \%$ greater than $\mathrm{P}$ balance in P-based manure (Table 1C). Shifting from N- based (279 $\mathrm{kg} \mathrm{P} \mathrm{ha}^{-1}$ ) to P-based compost management resulted in a $45 \%$ reduction in $\mathrm{P}$ balance. Lower than anticipated crop P removal, reflecting lower than estimated yield potential, resulted in $\mathrm{P}$ balances that were greater than zero in both P-based manure and P-based compost treatments. The 0 and $112 \mathrm{~kg} \mathrm{~N} \mathrm{ha}^{-1}$ treatments had negative $\mathrm{P}$ balances $(-54$ and $-59 \mathrm{~kg} \mathrm{P} \mathrm{ha}^{-1}$ ) (Table 1C).

The $\mathrm{P}$ balance in the alfalfa years was least negative during the 2006 growing season (establishment year) due to the addition of $10 \mathrm{~kg} \mathrm{P} \mathrm{ha}^{-1}\left(22 \mathrm{~kg} \mathrm{P}_{2} \mathrm{O}_{5} \mathrm{ha}^{-1}\right)$ as starter fertilizer combined with a relatively low yield that year. In 2007, severe drought resulted in low alfalfa DM yields as well, resulting in low $\mathrm{P}$ uptake and a relatively small negative $\mathrm{P}$ balances for all treatments that year (Table 1B, C). In years with good growing conditions, $\mathrm{P}$ balances were more negative reflecting higher yields and hence higher P uptake. A shift from N-based to Pbased manure resulted in a $27 \%$ less negative balance in the alfalfa years due to the greater yields when $\mathrm{N}$-based rates had been applied in the corn years. A change from N-based to Pbased compost management resulted in only $7 \%$ difference in P balance (Table 1B, C).

The cumulative 5-year balance for the alfalfa years was more negative in high-yielding treatments (N-based manure, $\mathrm{N}$-based compost, and P-based compost). Nitrogen-based manure removed $42 \mathrm{~kg} \mathrm{ha}^{-1}$ more $\mathrm{P}$ than the P-based manure, whereas no differences were found between $\mathrm{N}$-based compost and P-based compost (Table 1C).

The greatest 10-year $\mathrm{P}$ balance was obtained with $\mathrm{N}$-based manure application $\left(210 \mathrm{~kg} \mathrm{P} \mathrm{ha}^{-1}\right)$, reflecting the high manure application rates. Shifting from N-based to P-based

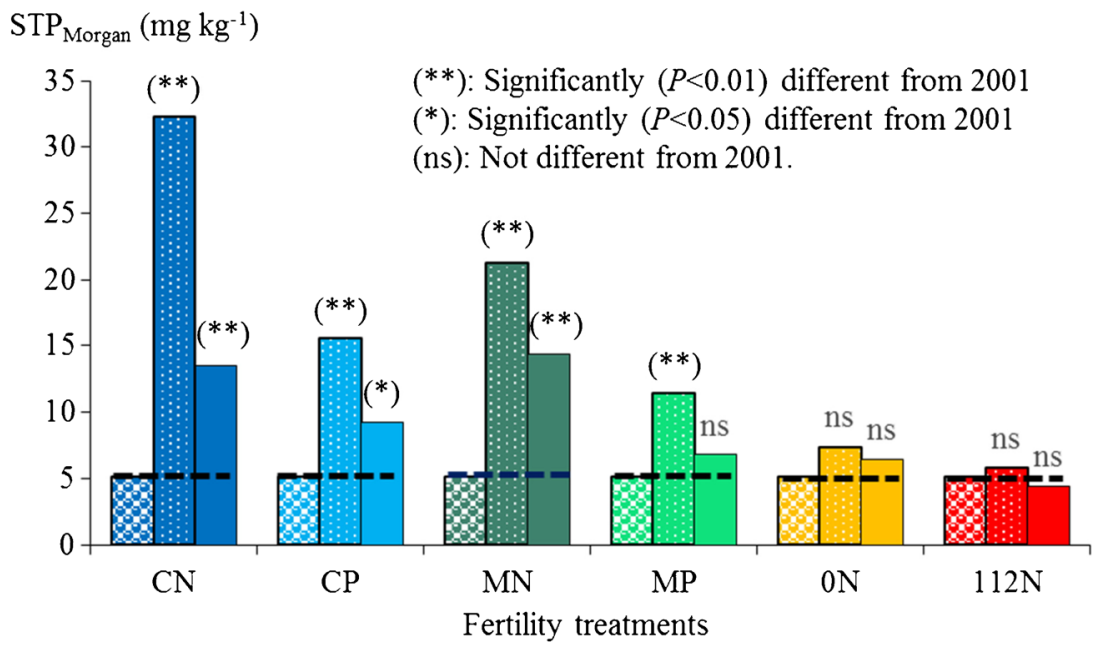

Fig. 2 Soil test P (STP) concentration in April 2001, after 5 years of corn silage production with annually spring application of composted separated dairy solids, liquid dairy manure, and inorganic $\mathrm{N}$ fertilizer (April 2006), and after 5 years of alfalfa in the rotation without composted separated dairy solids, liquid dairy manure, and inorganic $\mathrm{N}$ fertilizer (April 2011) in central New York. Specific treatments include: $\mathrm{N}$-based composted dairy solids $\left(\mathrm{CN}, 74 \mathrm{Mg} \mathrm{ha}^{-1}\right), \mathrm{P}$ removal based composted dairy solids $\left(\mathrm{CP}, 46 \mathrm{Mg} \mathrm{ha}^{-1}\right)$, N-based liquid dairy manure without incorporation ( $\mathrm{MN}, 196 \mathrm{~m}^{3} \mathrm{ha}^{-1}$ ), P removal based liquid dairy manure with incorporation of manure directly following application (MP, $\left.68 \mathrm{~m}^{3} \mathrm{ha}^{-1}\right)$, starter $\mathrm{N}$ application only $(0 \mathrm{~N})$, and $112 \mathrm{~kg} \mathrm{~N}$ ha $^{-1}$ sidedressed N (112 N). Figure 2 is comparing STP concentration in April 2006 and April 2011 with STP concentration in April 2001 for each fertility treatment. Dotted lines are referring to initial STP concentrations and that all treatments had similar STP levels. **: significant at $P \leq 0.01 ; *$ : significant at $P \leq 0.05 ; N S$ or $n s$ : not significant 
manure reduced the 10 -year balance to $-30 \mathrm{~kg} \mathrm{P} \mathrm{ha}^{-1}$, a $240 \mathrm{~kg} \mathrm{ha}^{-1}$ reduction. A shift from N-based to P-based compost reduced the $\mathrm{P}$ balance by $114 \mathrm{~kg} \mathrm{ha}^{-1}$ to $14 \mathrm{~kg} \mathrm{P} \mathrm{ha}^{-1}$, close to zero reflecting effectiveness of alfalfa to mine $P$ in the soil over time. Phosphorus balances were -170 and $-163 \mathrm{~kg} \mathrm{ha}^{-1}$ for the 0 and $112 \mathrm{~kg} \mathrm{~N} \mathrm{ha}^{-1}$ treatments, respectively (sum of 5-year $\mathrm{P}$ balances in the corn-alfalfa rotation; Table 1C).

\subsection{Soil test $P$ buildup and drawdown}

After 5 years of repeated annual manure application based on corn $\mathrm{N}$ needs, the STP levels increased 4-fold (to $21.3 \mathrm{mg} \mathrm{P} \mathrm{kg}{ }^{-1}$ ) compared with the initial levels (5.1 $\mathrm{mg} \mathrm{kg}^{-1}$ ). In comparison, STP concentration increased 2-fold compared with the initial levels with Pbased manure applications. Soil test $\mathrm{P}$ increased by 6fold with $\mathrm{N}$-based compost (32.3 $\mathrm{mg} \mathrm{P} \mathrm{kg}^{-1}$ ) versus 3fold with P-based compost management. Both N-based manure and compost exceeded the $20 \mathrm{mg} \mathrm{kg}^{-1} \mathrm{STP}$ levels, beyond which no further $\mathrm{P}$ fertilizer addition is recommended as crop response to extra $\mathrm{P}$ is unlikely (Ketterings et al. 2005). The two and 3-fold STP concentration increases with P-based manure and compost managements reflected primarily the lower than expected yields. Soil test $\mathrm{P}$ remained unchanged with inorganic $\mathrm{N}$ management, reflecting the ability of the soil to supply sufficient $\mathrm{P}$ when the Morgan STP concentration is classified as high.

Soil test $\mathrm{P}$ decreased during the alfalfa years in all the organic treatments yet remained categorized as high after the complete rotation (STP $>4.5 \mathrm{mg} \mathrm{kg}^{-1}$ ). Soil test $\mathrm{P}$ decreased from 21.3 to 14.3 and 11.4 to $6.8 \mathrm{mg} \mathrm{P} \mathrm{kg}^{-1}$ when following $\mathrm{N}$-based and P-based manure rates. Soil test $\mathrm{P}$ decreased from 32.3 to 13.5 and from 15.6 to $9.2 \mathrm{mg} \mathrm{P} \mathrm{kg}^{-1}$ in the alfalfa years following N-based and P-based compost additions in the preceding corn years, respectively. Soil test $\mathrm{P}$ remained unchanged in both inorganic controls. While the STP concentration after 10 years was classified just above the agronomic critical value of $4.5 \mathrm{mg} \mathrm{kg}^{-1}$ in the zero $\mathrm{N}$ control treatment, it was classified just below the agronomic critical value where $112 \mathrm{~kg} \mathrm{~N} \mathrm{ha}{ }^{-1}$ had been applied. The lack of a significant change in STP concentration in the inorganic treatments, despite the negative balances, might reflect the ability of the surface soil to supply $\mathrm{P}$ when classified as high combined with the ability of the root system of alfalfa to draw P from deeper layers and redistribute $\mathrm{P}$ to the top soil layer.

After 10 years, STP concentration in P-based manure was similar to its initial levels $\left(5.1 \mathrm{mg} \mathrm{kg}^{-1}\right)$, indicating that with Pbased manure management in corn years STP levels can be maintained sustainably over the rotation. Soil test $\mathrm{P}$ remained 2.6- and 1.8-fold higher than the initial levels in compost $(\mathrm{N}$ based and P-based) and 2.8-fold in N-based manure management over the 10 -year rotation, indicating that compost and N-based manure management in corn years will elevate STP concentration over time. Findings of this study indicated quicker STP buildup in a 5-year corn with manure and compost additions than STP drawdown when alfalfa was grown without $\mathrm{P}$ addition, similar to results reported by Mallarino and Prater (2007) who found that the rate of STP drawdown was slower than STP buildup in a long-term cornsoybean rotation. These results suggest that more years of crop $P$ removal without $P$ addition are needed to reduce STP levels in the study by Mallarino and Prater (2007), and that could also be the case for STP concentrations in N-based manure and $\mathrm{N}$ - and P-based compost treatments here.

\subsection{Relationship between phosphorus balances and STP concentration}

Differences in $\mathrm{P}$ balances for manure and compost resulted in quicker STP buildup when compost was the P source than when liquid manure had been applied. To increase the Morgan STP concentration by $1 \mathrm{mg} \mathrm{kg}^{-1}, 11.1 \mathrm{~kg}$ surplus P $\mathrm{ha}^{-1}$ was needed when compost was the $P$ source versus $25 \mathrm{~kg}$ surplus $\mathrm{P} \mathrm{ha}^{-1}$ when liquid manure was used (Fig. 3a). In the P-based treatments, $17 \mathrm{~kg} \mathrm{P} \mathrm{ha}^{-1}$ excess $\mathrm{P}$ (balance) was required to increase the Morgan STP concentration by $1 \mathrm{mg} \mathrm{kg}^{-1}$. These results are consistent with findings of Haden et al. (2007) who found $18 \mathrm{~kg} \mathrm{P} \mathrm{ha}^{-1}$ was needed to raise Morgan-extractable STP concentration by $1 \mathrm{mg} \mathrm{kg}^{-1}$, without the presence of a crop (laboratory study). Differences between the result of current study and results of Haden et al. (2007) could be explained by the fact that in the current study, the relationship between P balance and STP buildup was assessed, considering P removal by both corn and alfalfa over the long-term rotation, whereas Haden et al. (2007) used the amount of P applied only.

The rate of STP drawdown during the alfalfa years was quicker when compost had been used in the corn year than when manure was the P source (Fig. 3b, d). A P removal of $13.7 \mathrm{~kg} \mathrm{P} \mathrm{ha}^{-1}$ was needed to decrease the STP concentration by $1 \mathrm{mg} \mathrm{kg}^{-1}$ when compost was the fertility source during the corn years versus a $27.7 \mathrm{~kg} \mathrm{P} \mathrm{ha}^{-1}$ removal required to decrease STP concentration by $1 \mathrm{mg} \mathrm{kg}^{-1}$ when manure was applied to corn. These results might reflect differences in $\mathrm{P}$ composition between the two sources, but it is also possible that the rate of STP drawdown is impacted by initial STP levels as suggested by Indraratne et al. (2009).

Over the 10-year rotation, STP buildup was quicker in compost $\left(0.078 \mathrm{mg} \mathrm{kg}^{-1}\right.$ per $1 \mathrm{~kg}$ excess $\mathrm{P}$ budget ha $\left.{ }^{-1}\right)$ than manure $\left(0.039 \mathrm{mg} \mathrm{kg}^{-1}\right.$ per $1 \mathrm{~kg}$ excess $\mathrm{P}$ budget $\left.\mathrm{ha}^{-1}\right)$ (Fig. 3e). These results suggest $P$ source differences, consistent with Pagliari and Laboski (2013) who reported a greater amount of orthophosphate in manure than in compost. 
Morgan STP $\left(\mathrm{mg} \mathrm{kg}^{-1}\right)$
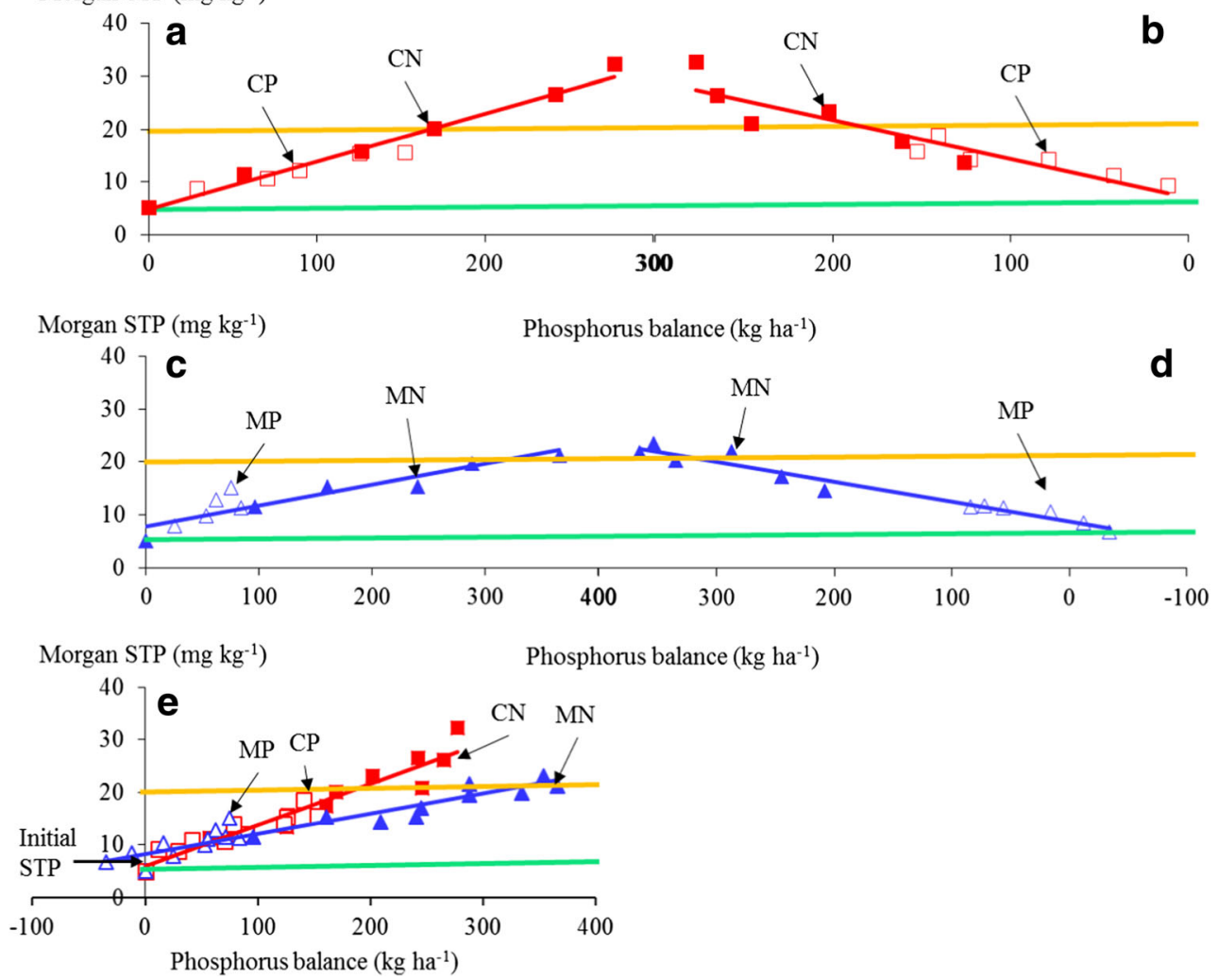

Fig. 3 Increase (a and $\mathbf{c}$ ) and decrease (b and $\mathbf{d}$ ) in Morgan-extractable soil test P (STP) concentration (0-20-cm depth; $\left.\mathrm{mg} \mathrm{kg}^{-1}\right)$, with cumulative $\mathrm{P}$ balance in composted dairy solids and liquid dairy manure from 2001 to 2005 (corn years) and from 2006 to 2010 (alfalfa years), and the relationship between cumulative $\mathrm{P}$ balance and increase in STP concentration over the rotation (2001-2010) with composted dairy solids and liquid dairy manure (e). The regression for STP concentration increase and decrease as a function of $\mathrm{P}$ balance when compost was the

\subsection{Soil P over depths}

Sampling over depth at the end of the 10-year study showed that STP levels were below the $20 \mathrm{mg} \mathrm{kg}^{-1}$ critical level for agronomic $\mathrm{P}$ application, as documented in Ketterings et al. (2003b) in all treatments and depths. Phosphorus changes occurred in the surface $0-5$ and $5-20 \mathrm{~cm}$ depths primarily. In $0-5 \mathrm{~cm}$ soil profile, the highest STP levels were measured in both N-based manure and compost (18.8 $\mathrm{mg} \mathrm{kg}^{-1}$; averaged over the two treatments) (Fig. 4). A shift from N-based to P-based compost resulted in $21 \%$ lower STP concentration in the top $5 \mathrm{~cm}$ of soil versus $37 \%$ lower STP concentration with a change from N-based to P-based manure management. In 5-20 cm soil layer, the highest STP concentrations were measured in $\mathrm{N}$-based manure (11 mg kg ${ }^{-1}$ ) and N-based compost (8.9 mg kg-1) (Fig. 4). A shift from N-based to P-based manure and compost did not decrease STP concentration at this soil depth. Soil test P concentrations decreased with depth beyond $20 \mathrm{~cm}$, independent of treatments. These results reflect the application of manure and compost to the topsoil layer $(0-20 \mathrm{~cm}$ depth), crop $\mathrm{P}$ removal from

fertility source were (a) STP $\left(\mathrm{mg} \mathrm{kg}^{-1}\right)=0.0906 \times\left(\mathrm{kg} \mathrm{ha}^{-1}\right)+4.7685$, and (b) STP $\left(\mathrm{mg} \mathrm{kg}^{-1}\right)=0.073 \times\left(\mathrm{kg} \mathrm{ha}^{-1}\right)+6.8757$. The regression for STP concentration increase and decrease as a function of $\mathrm{P}$ balance when manure was the fertility source were (c) STP $\left(\mathrm{mg} \mathrm{kg}^{-1}\right)=0.0397 \times$ $\left(\mathrm{kg} \mathrm{ha}^{-1}\right)+7.7415$, and (d) STP $\left(\mathrm{mg} \mathrm{kg}^{-1}\right)=0.0365 \times\left(\mathrm{kg} \mathrm{ha}^{-1}\right)+$ 8.7213. The regression equations for STP increase (over a 10-year period) due to excess $\mathrm{P}$ balances with compost and manure addition were $\mathrm{STP}_{\text {compost }}=0.0784 \times+6.001$, and $\mathrm{STP}_{\text {manure }}=0.0386 \times+8.1655$

deeper subsoil, and no accumulation of $\mathrm{P}$ over time, beyond the surface layer $(0-20 \mathrm{~cm}$ depth$)$.

\subsection{Implications}

Understanding P buildup and drawdown as a function of $\mathrm{P}$ balance over a full rotation will help determine how long farmers can continue to add manure and compost at $\mathrm{N}$ or P-based rates before further application is limited by environmental regulations. In NY, Cela et al. (2014) identified $13 \mathrm{~kg} \mathrm{P} \mathrm{ha}^{-1}$ as a feasible whole-farm $\mathrm{P}$ balance (upper level). Assuming linear buildup of STP with P application and a P balance of $13 \mathrm{~kg} \mathrm{P}$ $\mathrm{ha}^{-1}$, STP concentration in manure and compost amended corn and alfalfa rotations (with equal years for each) would increase by 5.2 and $10.1 \mathrm{mg} \mathrm{kg}^{-1}$ each 10 years, respectively. Thus, soils with an initial STP concentration of $20 \mathrm{mg} \mathrm{kg}^{-1}$ Morgan P (the STP beyond which the agronomic $\mathrm{P}$ recommendation becomes zero in NY) will take 39 years to reach a STP concentration of $40 \mathrm{mg} \mathrm{kg}^{-1}$ Morgan P (the STP beyond which no further P application is allowed if $\mathrm{P}$ transport risk is high if manure is the 


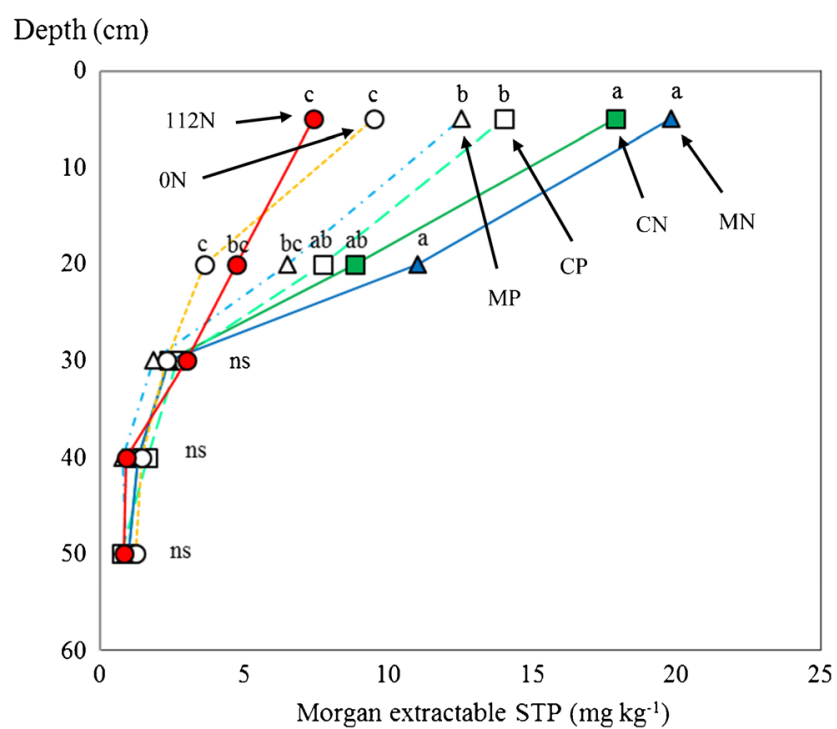

Fig. 4 Effects of fertility treatments for corn in a 5-year corn and 5-year alfalfa rotation on Morgan-extractable soil test P (STP) concentration over depth $(0-50 \mathrm{~cm})$ after one full cycle of the rotation (10 year). $C N$ : $\mathrm{N}$-based composted dairy solids $\left(74 \mathrm{Mg} \mathrm{ha}^{-1}\right), C P$ : P-based composted dairy solids (46 $\mathrm{Mg} \mathrm{ha}^{-1}$ ), $M N$ : N-based liquid dairy manure $\left(196 \mathrm{~m}^{3} \mathrm{ha}^{-1}\right), M P$ : P-based liquid dairy manure $\left(68 \mathrm{~m}^{3} \mathrm{ha}^{-1}\right.$; immediately incorporated), and $112 \mathrm{~N}: 112 \mathrm{~kg} \mathrm{~N} h a^{-1}$ side-dressed $\mathrm{N}$ in addition to a small starter in the corn years. No manure or compost was applied in the alfalfa years. Means for fertility treatments that are followed by different letters are significantly different $(P \leq 0.05)$. Letters compare each variable at each depth. $N S$ : non-significant

$\mathrm{P}$ source) versus 20 years with compost as the $\mathrm{P}$ source. The 10 year $\mathrm{P}$ balance for $\mathrm{N}$-based manure management (no incorporation of manure) in our study was $21 \mathrm{~kg} \mathrm{P} \mathrm{ha}^{-1}$ year $^{-1}$ ([5-year P balance for corn $+\mathrm{P}$ balance for alfalfa $] / 10$; Table 1 ), suggesting that long-term implementation of $\mathrm{N}$-based manure management will result in whole farm balances that exceed the feasible balances for P established by Cela et al. (2014). With P-based management, STP levels can be maintained over time. Results of current study highlight the importance of regular soil testing so that decisions can be made to reduce manure application rates and supplement lower manure or compost rates with $\mathrm{N}$ fertilizer where needed to avoid excessive $\mathrm{P}$ levels. Improvement in estimating yield potentials can help target crop P removal rates and therefore avoid positive $\mathrm{P}$ balances. Including cover crops during the corn years could be a viable management practice to improve $\mathrm{N}$ and $\mathrm{P}$ cycling, allowing for greater $\mathrm{N}$ supply in the P-based systems. Also, the use of manure and compost sources with greater $\mathrm{N} / \mathrm{P}$ ratios (precision feeding) can reduce $\mathrm{P}$ balances over time and thus reduce the rate of STP buildup.

\section{Conclusions}

The results of this study indicated the potential for maintaining STP levels with a shift from N-based to P-based manure management and resulted in timelines for $\mathrm{P}$ buildup over rotations with N-based manure management while also highlighting the challenge in accurately predicting P-removal rates. Yields in the corn years of the rotation suggest that a shift to P-based manure applications requires additional $\mathrm{N}$ fertilizer in corn years and possibly sulfur addition in later years in the alfalfa portion of the rotation. Decreasing the number of years under corn versus the number of years under alfalfa in the rotation could allow for manure and compost addition using N-based manure rates. Results of the current study suggest that $\mathrm{P}$ balance assessment is useful to predict the rate of STP buildup and drawdown over the rotation, with implications for decisions about source and rate of $\mathrm{P}$ addition, length of crop rotations, and management practices to maintain yield and reduce P runoff risk.

Acknowledgements The authors would like to thank Aurora Ridge Dairy Farm for providing the liquid dairy manure. Composted dairy solids were supplied by Willet Dairy (years 1 and 2) and Fessenden Dairy (years 3-5). We thank Francoise Vermeylen from the Cornell University Statistical Consulting Unit for statistical advice. This material is based on work that was supported by Federal Formula Funds and the National Institute of Food and Agriculture, US Department of Agriculture, under award number 2013-68002-20525. Any opinions, findings, conclusions, or recommendations expressed in this publication are those of the author(s) and do not necessarily reflect the view of the US Department of Agriculture.

\section{References}

AOAC (2000) Method 990.03: Protein (crude) in animal feed. AOAC Int., Rockville

Cela S, Ketterings QM, Czymmek KJ, Soberon M, Rasmussen C (2014) Characterization of nitrogen, phosphorus, and potassium mass balances in dairy farms in New York State. J Dairy Sci 97:1-19. doi:10. 3168/jds.2014-8467

Dairy One (2007) Forage laboratory services - procedures: VI. Manure. http://dairyone.com/analytical-services/agronomy-services/manure/ (accessed 13 Sept. 2014)

Dodd JR, Mallarino AP (2005) Soil-test phosphorus and crop grain yield responses to long-term phosphorus fertilization for corn-soybean rotations. Soil Sci Soc Am J 69:1118-1128. doi:10.2136/ sssaj2004.0279

Eghball B, Power JF (1999) Phosphorus- and nitrogen-based manure and compost applications: corn production and soil phosphorus. Soil Sci Soc Am J 63:895-901. doi:10.2136/sssaj1999.634895x

Greweling T, Peech M (1965) Chemical soil test. Agric. Exp. Stn. Bull. 960. Cornell Univ., Ithaca.

Griffin TS, Honeycutt CW, He Z (2003) Changes in soil phosphorus from manure application. Soil Sci Soc Am J 67:645-653. doi:10.2136/ sssaj2003.6450

Haden VR, Ketterings QM, Kahabka JE (2007) Factors affecting change in soil test phosphorus following manure and fertilizer application. Soil Sci Soc Am J 71:1225-1232. doi:10.2136/sssaj2006.0230

Hoskins B, Wolf A, Wolf N (2003) Dry matter analysis. In: Peter J (ed) recommended methods of manure analysis (A3769). Univ. of Wisconsin Coop. Ext., Madison. 14-17

Huang S, Ma Y, Bao D, Guo D, Zhang S (2011) Manures behave similar to superphosphate in phosphorus accumulation in long-term field soils. Int J Plant Prod 5:135-146 
Indraratne SP, Hao X, Chang C, Godlinski F (2009) Rate of soil recovery following termination of long-term cattle manure applications. Geoderma 150:415-423. doi:10.1016/j.geoderma.2009.03.002

Kashem MA, Akinremi OO, Racz GJ (2004) Phosphorus fractions in soil amended with organic and inorganic phosphorus sources. Can J Soil Sci 84:83-90. doi:10.4141/S03-018

Ketterings QM, Klausner SD, Czymmek KJ (2003a) Nitrogen guidelines for field crops in New York. Dep. Crop Soil Sci. Ext. Ser. E03-16. Cornell Univ., Ithaca

Ketterings QM, Czymmek KJ, Klausner SD (2003b) Phosphorus guidelines for field crops in New York. Ext. Ser. E03-15. Dep. Crop Soil Sci., Cornell Univ., Ithaca

Ketterings QM, Klausner SD, Czymmek KJ (2003c) Potassium guidelines for field crops in New York. Ext. Ser. E03-14. Dep. of Crop Soil Sci. Cornell Univ., Ithaca

Ketterings QM, Swink SN, Godwin G, Czymmek KJ, Albrecht GL (2005) Maize silage yield and quality response to starter phosphorus fertilizer in high phosphorus soils in New York. J Food Agric Environ 3:237-242

Ketterings QM, Godwin G, Gami S, Dietzel K, Lawrence JR, Barney P, Kilcer T, Stanyard M, Albers C, Cherney JH, Cherney D, Czymmek $\mathrm{KJ}$ (2012) Soil and tissue testing for sulfur management of alfalfa in New York State. Soil Sci Soc Am J 76:298-306. doi:10.2136/ sssaj2010.0437

Ketterings QM, Godwin G, Barney P, Lawrence JR, Aldrich B, Kilcer T (2013) Shallow mixing of surface soil and liquid dairy manure conserves nitrogen while retaining surface residue. Agron Sustain Dev 33:507-517. doi:10.1007/s13593-013-0141-1

Kleinman PJA, Sharpley AN, Moyer BG, Elwinger GF (2002) Effect of mineral and manure phosphorus sources on runoff phosphorus. J Environ Qual 31:2026-2033. doi:10.2134/jeq2002.2026

Kumaragamage D, Flaten D, Akinremi OO, Sawka C, Zvomuya F (2011) Soil test phosphorus changes and phosphorus runoff losses in incubated soils treated with livestock manures and synthetic fertilizer. Can J Soil Sci 91:375-384. doi:10.4141/cjss10004

Li Q, Li JM, Cui XL, We DP, Ma YB (2012) On-farm assessment of biosolids effects on nitrogen and phosphorus accumulation in soils. J Integr Agr 11:1545-1554. doi:10.1016/S2095-3119(12)60155-5

Littell RC, Milliken GA, Stroup WW, Wolfinger RD (1996) SAS system for mixed models. SAS Inst, Cary

Mallarino AP, Prater J (2007) Corn and soybean grain yield, phosphorus removal, and soil-test responses to long-term phosphorus fertilization strategies. p. 241-253. In The Integrated Crop Management Conf. Proceedings. Nov. 29-30, 2007. Ames, IA. Iowa State Univ. Extension

Meisinger JJ, Schepers JS, Raun WR (2008) Crop nitrogen requirement and fertilization. In: Schepers JS, Raun WR (eds) Nitrogen for agricultural systems. Agron. Monogr. 49. ASA, Madison, pp 563-612. doi:10.2134/agronmonogr49.c14
Morgan MF (1941) Chemical soil diagnosis by the universal soil testing system. Bull. 450. Connecticut Agric. Exp. Stn., New Haven

Murphy J, Riley JP (1962) A modified single solution method for determination of phosphates in natural waters. Anal Chim Acta 27:3136. doi:10.1016/S0003-2670(00)88444-5

National Agricultural Statistics Service (2015) New York crop and livestock report January 2015. USDA-NASS New York Field Office, Albany, NY. https://www.nass.usda.gov/Quick_Stats/Ag Overview/stateOverview.php?state=NEW\%20YORK

Pagliari PH, Laboski CA (2013) Dairy manure treatment effects on manure phosphorus fractionation and changes in soil test phosphorus. Biol Fertil Soils 1-13. doi: 10.1007/s00374-013-0798-2

Randall GW, Iragavarapu TK, Evans SD (1997) Long-term P and K applications: I. Effect on soil test incline and decline rates and critical soil test levels. J Prod Agric 10:565-571

Sadeghpour A, Hashemi M, Weis SA, Spargo JT, Mehrvarz S, Herbert SJ (2015) Assessing tillage systems for reducing ammonia volatilization from spring-applied slurry manure. Commun Soil Sci Plant Anal 46:724-735. doi:10.1080/00103624.2015.1005223

Sadeghpour A, Ketterings QM, Godwin GS, Czymmek KJ (2016a) Nitrogen- vs phosphorus-based manure and compost management of corn. Agron J 108:185-195. doi:10.2134/agronj2015.0218

Sadeghpour A, Ketterings QM, Vermeylen F, Godwin GS, Czymmek KJ (2016b) Soil properties under nitrogen- vs phosphorus-based manure and compost management of corn. Soil Sci Soc Am J 80: 1272-1282. doi:10.2136/sssaj2016.03.0086

Sadeghpour A, Ketterings QM, Godwin GS, Czymmek KJ (2017) Under- or over-application of nitrogen impact corn yield, quality, soil, and environment. Agron J 109:343-353. doi:10.2134/ agronj2016.06.0355

SAS Institute (2009) SAS user's guide: Statistics. Version 7, 4th ed. SAS Inst, Cary

Schulte EF, Kelling KA (1991) National corn handbook. NCH-16: Crop fertilization. Plant analysis: a diagnostic tool. Purdue University, West Lafayette, IN. http://www.ces.purdue.edu/extmedia/nch/nch46.html (accessed 6 June 2016)

Sirois PK, Reuter MJ, Laughlin CM, Lockwood PJ (1994) A method for determining macro and micro elements in forages and feeds by inductively coupled plasma atomic emission spectrometry. Spectroscopist 3:6-9

Storer DA (1984) A simple high volume ashing procedure for determination of soil organic matter. Commun Soil Sci Plant Anal 15:759772

Toth JD, Dou Z, Ferguson JD, Galligan DT, Ramberg CF (2006) Nitrogen vs. phosphorus-based dairy manure applications to field crops: nitrate and phosphorus leaching and soil phosphorus accumulation. J Environ Qual 35:2302-2312. doi:10.2134/jeq2005.0479 